\title{
The African Proverbs Project and After
}

\author{
John S. Mbiti, Faculty of Theology, University of Bern, Bern, Switzerland \\ (john.mbiti@freesurf.ch)
}

\begin{abstract}
The Pew Charitable Trusts financed the African Proverbs Project with Dr Stan Nussbaum as co-ordinator, for three years (1993-1996). He assembled a number of scholars who had collected and studied proverbs. The purpose of the Project was to encourage further work of collecting, studying and publishing proverbs. It organised international and interdisciplinary symposia and embarked on three types of publications.

One kind of publication was the African Proverbs Series, with Prof. John Mbiti as editor. Five volumes were published in 1997, each with proverbs from respectively Ethiopia, Uganda, Lesotho, Burkina Faso and Ghana. Their size ranged from 584 to 1497 proverbs in African languages, with translations into English or French. Another set of publications with the Rev. Joshua Kudadjie as editor, covered proverbs for preaching and teaching purposes. Three volumes have come from Malawi, Ghana and Liberia. The Project also published an annotated bibliography by Prof. Wolfgang Mieder. The report from one of the symposia appeared in 1997.

The third manner of publication is in the form of a CD-ROM edited by Dr Stan Nussbaum and published in 1996. This is a very comprehensive collection and source of material that includes, inter alia, books from the Project, some 28000 proverbs, a bibliography with 1000 items, summaries and extracts from published collections, and a language survey of work on proverbs.

The Project has generated both local and international interest in African paremiography and paremiology. Four academic institutions in South Africa, Kenya, Ghana and the Ivory Coast, with links to others in Africa, Europe and America, are continuing this work on proverbs.
\end{abstract}

Keywords: AFRICAN PROVERBS PROJECT, AFRICAN PROVERBS SERIES, PROVERB, PAREMIOGRAPHY, PAREMIOLOGY

Opsomming: Die African Proverbs Project en daarna. Die Pew Charitable Trusts het die African Proverbs Project, met dr. Stan Nussbaum as koördineerder, vir drie jaar (1993-1996) gefinansier. Hy het 'n aantal vakkundiges bymekaargebring wat spreekwoorde versamel en bestudeer het. Die doel van die projek was om verdere werk ten opsigte van die versameling, bestudering en publikasie van spreekwoorde aan te moedig. Dit het internasionale en interdissiplinêre simposia georganiseer en drie soorte publikasies onderneem.

Een soort publikasie was die African Proverbs Series, met prof. John Mbiti as redakteur. Vyf bande is in 1997 gepubliseer, elkeen met spreekwoorde van onderskeidelik Ethiopië, Uganda, Lesotho, Burkina Faso en Ghana. Hul omvang het gewissel van 584 tot 1497 spreekwoorde in Afrikatale, met vertalings in Engels en Frans. 'n Ander stel publikasies, met eerw. Joshua Kudadjie as redakteur, het spreekwoorde vir preek- en onderwysdoeleindes gedek. Drie dele is afkomstig van Malawi, Ghana en Liberië. Die projek het ook 'n geannoteerde bibliografie deur prof. Wolfgang Mieder gepubliseer. Die verslag van een van die simposia het in 1997 verskyn.

Die derde manier van publikasie is in die vorm van 'n CD-ROM, deur dr. Sam Nussbaum geredigeer en in 1996 gepubliseer. Dit is 'n baie omvattende versameling en bron van materiaal wat 
onder andere boeke van die projek, ongeveer 28000 spreekwoorde, 'n bibliografie met 1000 items, opsomming en uittreksels van gepubliseerde versamelings en 'n taaloorsig van werk oor spreekwoorde insluit.

Die projek het sowel plaaslike as internasionale belangstelling in die paremiografie en paremiologie van Afrika gewek. Vier akademiese instellings in Suid-Afrika, Kenia, Ghana en die Ivoorkus met skakels met ander in Afrika, Europa en Amerika, sit hierdie werk oor spreekwoorde voort.

Sleutelwoorde: AFRICAN PROVERBS PROJECT, AFRICAN PROVERBS SERIES, SPREEKWOORD, PAREMIOGRAFIE, PAREMIOLOGIE

\section{Short Background to the Project}

By sheer coincidence, Dr Sivgard von Sicard at the Selly Oak Colleges in Birmingham, England gave a short car ride to Dr Stan Nussbaum from Colorado, United States of America and Prof. John Mbiti from Kenya in the spring of 1992. The latter two had not met before. A casual conversation ensued, in which Dr Nussbaum mentioned that while working in Lesotho as a Mennonite missionary he had been struck by the potency of African proverbs. On his part Prof. Mbiti said that he had a keen interest in such proverbs and had collected about ten thousand of them, both published and unpublished. Would Prof. Mbiti be interested in a project that Dr Nussbaum was planning, to focus on African proverbs? Certainly he would. The two arranged to meet again and discuss the project more thoroughly. This they did in Switzerland a few months later. By then the Pew Charitable Trusts of Philadelphia had formally made a grant for the "African Proverbs Project", with Dr Nussbaum as the coordinator. The grant was to run for three years, 1993-1996, without renewal.

\section{Setting up the Work}

Dr Nussbaum contacted a few scholars who formed the working group for the Project. It comprised: Dan Hoffman (United States of America), Joshua Kudadjie (Ghana), John Mbiti (Kenya), Laurent Nare (Burkina Faso), Stan Nussbaum (United States of America, co-ordinator), John Pobee (Ghana), and Willem Saayman (Republic of South Africa). Apart from Dr Nare who had done a doctoral thesis on Mossi proverbs and the Jewish Bible, none of the committee members were "academic experts" on proverbs as such. But they all shared the necessary interest. The group recruited collectors (contributors) and mapped the direction of work to be covered. The world's leading paremiologist Prof. Wolfgang Mieder of the University of Vermont, United States of America, gave the Project enormous support through a bibliographical publication ${ }^{1}$, participating at one of its conferences, personal consultation and ongoing interest.

As the co-ordinator explained it, the main purpose of the Project was "to promote collection, publication and study of African proverbs with particular 
attention to their relationship to Christian mission, their role in modern Africa and their significance for a number of academic disciplines." To put the Project into action, the group made plans to cover five areas:

(1) Two international conferences.

(2) Publication of five volumes of proverbs from different parts of the continent.

(3) Publication of three volumes of proverbs for teaching and preaching.

(4) "Endangered species".

(5) A bibliography of collections and records of proverbs in articles and books.

\subsection{The International Conferences}

The first five-day conference met at Ricatla Theological Seminary, Maputo, Mozambique in March 1995. It examined the relationship of proverbs to Christianity. Seventeen theologians and educators attended and presented papers. The second conference in October 1995 brought together thirty-seven participants from different disciplines, including historians, philosophers, cultural researchers, theologians and language scholars. The Missiology Department of the University of South Africa (UNISA), Pretoria hosted the symposium.

The papers presented at the two conferences are included on the CD-ROM that Dr Nussbaum later put together. (More on this, below.) Prof. Willem Saayman edited the papers from the second conference and the University of South Africa (UNISA) Press, Pretoria published them in 1997 under the title Embracing the Baobab Tree.

\subsection{Publication of Five Volumes}

The working group selected five areas where there were scholars that had collected proverbs in local languages. The group felt that the material from those areas would be representative for the whole continent, even if the number published amounted to a small fraction of the total wealth of proverbs in Africa. It chose Ethiopia and Uganda in Eastern Africa, Lesotho in Southern Africa, and Ghana and Burkina Faso in Western Africa. The group chose paremiographists (collectors) who already had enough proverbs or would enlarge their collections to constitute a book. These were Dr George Cotter for the Oromo proverbs in Ethiopia, Prof. Albert Dalfovo for the Lugbara proverbs in Uganda, Dr 'Makali Isabella Mokitimi (the only female) for the Basotho proverbs in Lesotho, Prof. Kofi A. Opoku for the Akan proverbs in Ghana, and both Fr Dr Laurent Nare and Fr François Xavier Damiba for the Mossi proverbs in Burkina Faso. It designated Prof. John Mbiti to be the general editor of the series. 
The "writers' group" consisting of the co-ordinator, collectors and general editor, worked out some guidelines for the five volumes. Among other things, the proverbs were to be published in their original African languages, with translations and short explanations in English (for four volumes) and French (for one volume). Each volume would have an introduction about the peoples concerned and their country, the place of proverbs in society, and elaboration on the themes that the proverbs addressed. The general editor's introduction would be included in all the volumes.

The "writers' group" also drew up a long list of themes that emerged from the proverbs. Among them are specifically religious themes like God, the departed (so-called ancestors); values and vices; sociological themes like marriage, the family, behaviour and food; life's journey from pregnancy to death and the hereafter; the human person and activities; environmental settings like plants, animals and birds. The volumes would have indices with alphabetical listings of the proverbs in original languages, topics and key words. Attention was to be given to gender expressions, so that as far as possible, inclusive language would be employed. Each proverb would be numbered for reference purposes. Hand-drawn illustrations were to be included, and each collector was free to find a local artist (illustrator) and to choose the proverbs to be illustrated. The general editor in close liaison with the collectors was to exercise editorial discretion and freedom over the volumes, as would be appropriate and necessary.

The University of South Africa (UNISA) Press, jointly with Asempa Publishers in Accra, Ghana, Daystar and Sefer Presses in Ibadan, Nigeria published the first four volumes in 1997, under the main heading of African Proverbs Series. Each has its own title. Volume one with a collection by George Cotter, Ethiopian Wisdom, Proverbs and Sayings of the Oromo People, 268 pp., contains a total of 1497 proverbs. It is in this respect also the largest of the five. Volume two has the collection by Kofi Asare Opoku, Hearing and Keeping. Akan Proverbs, 185 pp., with 600 proverbs. Volume three has the collection by Albert Dalfovo, Lugbara Wisdom, 185 pp., with 773 proverbs. Volume four is the collection by 'Makali I. Mokitimi, The Voice of the People. Proverbs of the Basotho, 118 pp., with 584 proverbs. The fifth volume with 999 proverbs was published in 1999, being the collection by François Xavier Damiba and Laurent Nare, Proverbes Mossi. Une Sélection, 202 pp., in Abidjan, Ivory Coast. ${ }^{2}$

Thus, the Series itself published a total of 4453 proverbs in its five volumes. This is obviously a very small portion of an estimated four million proverbs in two thousand African languages. The Project would have made additional publications in the Series, but there were no funds to continue beyond the initial period of three years. However, with this and other publications of the Project, enough interest has been generated for the work to continue, as will be indicated below.

\subsection{Publication of Proverbs for Teaching and Preaching}

As Dr Nussbaum explains, the purpose of this part of the Project "was much 
narrower - to encourage the use of African proverbs as aids to Christian moral instruction. These are intended as textbooks in Bible institutes and seminaries, as well as resources for church leaders. Each book contains an introductory chapter comparing and contrasting the values of African proverbs and the Bible. The book is an explanation of 350 to 500 local proverbs, showing how each could be used in Christian instruction." The following are the three books:

Rev. Joshua Kudadjie, Ga and Dangme Proverbs for Preaching and Teaching, Asempa Press, Accra, Ghana 2002. It contains 384 proverbs of which 100 in the $\mathrm{Ga}$ and Dangma languages respectively are annotated, 50 in each of the two languages with English translations (but not annotated), and a further 84 are used in the text.

Dr Abba Karnga, There is Diversity in Wisdom: 150 Bassa Proverbs from Liberia. A Bassa language edition exists (but publication details are indefinite at time of writing).

Dr David K. Mphande, Nthanthi za Chitonga za Kusambizgiya ndi Kutaulia (literally, Tonga Proverbs for Teaching and Preaching), a Kachere Book by CLAIM (Christian Literature Association in Malawi), Blantyre, Malawi 2001. The book contains 487 proverbs, of which 200 are annotated.

The current plan is to publish all three books in English on the Internet at http://www.afriprov.org. English editions are also under consideration by Asempa Press and the Kachere Series.

\section{4 "Endangered Species"}

One branch of the Project explored or searched for languages in which only a few proverbs, or none, had been collected. Some of these languages were not yet, or only recently became written languages. Six writers were designated to follow up this need. Efforts in this direction brought successful results, as the co-ordinator of the Project later pointed out: "Three lists were made in Burkina Faso and one each in Togo, South Africa and Tanzania. The average is about 400 proverbs per language; French or English translations are included. The project did not pay for printed publication of these; some would require further editing before that would be feasible. However, the existence of ANY list of proverbs can be a starting point from which a researcher may eventually produce a significant work."

This short list here also points to the fact that in many languages, no written collections exist. The Project assembled information on the languages having some published collections, the information about which is in the CDROM. 


\subsection{A Bibliography of Collections of Proverbs in Articles and Books}

One major attention of the Project was to search for and assemble paremiographical works on African proverbs. Dr Nussbaum took charge of this area. Prof. Wolfgang Mieder's African Proverb Scholarship and the yearly information in Proverbium: Yearbook of International Proverb Scholarship (1984-) of which he is editor, gave a boost to this dimension of the Project. Prof. Mieder's book has 279 entries. Dr Nussbaum found more publications, and by the time he put out the CD-ROM on the Project, the bibliography had grown to almost one thousand entries (999). The Project committee was astonished and overjoyed to find this wealth of collections and references. Yet, it was also clear that the list was not exhaustive, as it may have missed other publications especially in Spanish, Portuguese, and local African languages.

\section{Outcome and Follow-up of the Project}

The African Proverbs Project achieved a number of specific results, some of which took shape during the three-year period of the grant from the Pew Charitable Trusts. We summarise them as follows:

\subsection{Printed Publications}

We have indicated the five publications in book form under the African Proverbs Series. This small selection invites further work in the area of paremiography.

Two other publications under the same umbrella are the bibliography by Prof. W. Mieder and the conference report edited by Prof. W.A. Saayman both mentioned above. Mieder's book looks at what has been written, up to the time he collected the information. Saayman's book contains an interdisciplinary examination of proverbs - the methodology in paremiology, the role of proverbs in society and religion. The essays in the book examine individual themes from different disciplines, thus opening up African paremiology for further exploration.

The three books for teaching and preaching purposes also are to serve pedagogical and homiletical ends. At the same time they relate African proverbs to Biblical studies and theological issues that are stirring in contemporary Christianity.

\subsection{The CD-ROM}

Dr Stan Nussbaum assembled and edited a wealth of information and material relating to proverbs. This was published in the form of a CD-ROM, The African Proverbs. Collections, Studies, Bibliographies, by Global Mapping International 
(GMI), Colorado Springs, Colorado, 1996. Among other things, the CD-ROM contains some 28000 proverbs, 17 reprints of collections, the books mentioned above, as well as selections from published collections, and a bibliographical list of 999 items. There are "Key Pages" that are scanned images of the title pages, contents, introductions, bibliographies, etc. from about 200 proverb collections. A list of 33 titles of available collections informs on books that can be purchased. Language maps for each African country show the state of proverb research in each language on a scale of four, from "no known documentation" to "well documented". There are surveys of languages and work done in them on proverbs. The CD-ROM contains a word search for proverbs on particular themes or words. Texts from the $\mathrm{CD}$ can be printed or imported to other documents. This is an indispensable tool for the study of proverbs. ${ }^{3}$

\subsection{The Work on Proverbs Continues}

The initial grant from the Pew Charitable Trusts for the African Proverbs Project was for three years (1993-1996), without extension or renewal. The Project took shape in different forms as indicated above, and produced results by way of international symposia, publications of books and the CD-ROM. However, work on the proverbs did not stop there. It continues, particularly in East Africa, where two major activities have taken root and grown.

(a) The Project arranged with academic institutions in the Ivory Coast, Ghana, Kenya and South Africa to continue the work. These centres are: The Missiology Department, University of South Africa (UNISA), P.O. Box 392, Pretoria 0001, South Africa; the African Studies Centre, University of Ghana, P.O. Box 66, Legon, Ghana; the Institute Catholique de l'Afrique de l'Ouest (ICAO), 08 B.P. 22, Abidjan 08, Ivory Coast; and The Library, Hekima College, P.O. Box 21215, Nairobi, Kenya. UNISA planned a newsletter of African proverb research. Hekima College has emerged as the leading centre of activity. It has made additional collections of "endangered proverbs" in some of the smaller languages of Kenya, and more are planned. A growing group of about a dozen interested Kenyan scholars is holding occasional meetings to review progress on proverb study. Fr Edward Murphy, the Hekima librarian, is coordinating the effort.

(b) African Proverbs, Sayings and Stories at http://www. afriprov. org is a website on the Internet, originated, edited and moderated by Fr Joseph Healey, M.M., an American missionary based in Tanzania. An expanding circle of scholars is also involved in this effort. The site publishes one proverb each month, with its explanation and analysis generally linked to Biblical parallels. International writers contribute the proverbs, the largest number being Americans. The website is also a forum 
where people can post questions, or make comments connected to proverbs. It has book reviews, a few teaching resources and a 2002 African Proverbs Calendar, with a proverb for each day of the year.

\section{Conclusion}

The African Proverbs Project has sparked interest in individuals and institutions. It has encouraged (or challenged) them to pay closer attention to proverbs, to collect them, use them for pedagogical and preaching purposes, and eventually publish them as collections or in texts. It has stimulated academic scrutiny that may result in the interdisciplinary study of proverbs in various fields such as linguistics, history, philosophy, religion, sociology, literature and others. The two symposia indicated clearly that there are many persons all over Africa, working on proverbs in one way or another. They also brought to the forefront the two interrelated dimensions of collecting and studying proverbs (paremiography and paremiology). As the African soil is very rich in proverbs, these dimensions will occupy scholars for a long time. They go hand in hand, like the Kaguru (Tanzania) proverb describing how marriage gets sealed when both parties know each other: "Magongolo mamanyi gakigoweka sisingo" (Millipedes that know each other, coil their necks around each other).

It seems clear, that what started as a modest project continues to bear fruit much longer than its original life-span. In this way, the Project has acquired a significant and self-generating continuation. It is like the Sesotho proverb that says: "Sejo-senyane ha se fete molomo" (Little food can be shared by many).

\section{Endnotes}

1. Mieder, Wolfgang, 1994. African Proverb Scholarship. An Annotated Bibliography, Colorado Springs, U.S.A: African Proverbs Project. This work is also reproduced on the Project's CDROM. The publication contains summaries of 279 books, dissertations and articles, reproduced from the larger world-wide three volumes: Mieder, Wolfgang, 1982, 1990 and 1993. International Proverb Scholarship: An Annotated Bibliography. New York: Garland Publishing.

2. There is no indication of the publisher's name other than Série 'Proverbes Africains du Projet D'Étude des Proverbes Africains'. Copies of the book might be available through the two collectors whose addresses (in 2002) are: Évêque Laurent Nare, Diocèse de Koupéla, B.P. 51 Koupéla, Burkina Faso; and Abbé Professeur François Xavier Damiba, Grand Séminaire de Koumi, 01 B.P. 312 Bobo-Dioulasso 01, Burkina Faso.

3. The CD-ROM is distributed by Global Mapping International (website http://www . gmi. org/store/index.html) or an expanding network of African distributors (current list available by email from info@gmi.org). 